General Thoracic

Surgery

\title{
Receptor tyrosine kinase and phosphoinositide-3 kinase signaling in malignant mesothelioma
}

Philip A. Rascoe, MD, ${ }^{a}$ Xiaobo Cao, MD, Jonathan C. Daniel, MD, ${ }^{\text {a }}$ Steven D. Miller, MD, ${ }^{\text {a }}$ and W. Roy Smythe, MD

From the Department of Thoracic and Cardiovascular Surgery, Section of Thoracic Molecular Oncology, ${ }^{a}$ The University of Texas M.D. Anderson Cancer Center, Houston, Tex, and the Scott and White Medical Center, ${ }^{\mathrm{b}}$ The Texas A\&M University System Health Science Center, Temple, Tex.

Read at the Eighty-fourth Annual Meeting of The American Association for Thoracic Surgery, Toronto, Ontario, Canada, April 25-28, 2004.

Received for publication April 23, 2004; revisions received Oct 25, 2004; accepted for publication Nov 4, 2004.

Address for reprints: W. Roy Smythe, MD, Department of Surgery, Scott \& White Medical Center, The Texas A\&M University System Health Science Center, 2401 South 31st St, Temple, TX 76508 (E-mail: rsmythe@swmail.sw.org).

J Thorac Cardiovasc Surg 2005;130:393-400 $0022-5223 / \$ 30.00$

Copyright () 2005 by The American Association for Thoracic Surgery

doi:10.1016/j.jtcvs.2004.11.029
Objective: The phosphoinositide- 3 kinase signaling pathway is implicated in the development of malignancy and promotes cell-cycle progression and resistance to apoptosis. Malignant mesothelioma tumor specimens demonstrate high levels of the phosphoinositide-3 kinase downstream mediator phosphorylated Akt. Exposure of mesothelioma cell lines to LY294002, a phosphoinositide-3 kinase inhibitor, results in apoptotic cell death and decreased phosphorylated Akt in vitro and tumor burden reduction in vivo. Phosphoinositide-3 kinase is activated by cell-surface receptor tyrosine kinases. We sought to determine which receptors are present in mesothelioma and their role in cellular survival and phosphoinositide-3 kinase signaling.

Methods: Western blot analysis was performed to determine the relative expression of epidermal growth factor receptor, insulin-like growth factor receptor, and plateletderived growth factor receptor in the mesothelioma cell lines I-45 and REN and the mesothelial line Met5a. After exposure of mesothelioma lines to kinase inhibitors, a cell viability assay was performed, cell-cycle analysis was performed to determine the percentage of apoptosis, and Western blot analysis was performed for phosphorylated Akt.

Results: Inhibition of epidermal growth factor receptor resulted in apoptotic cell death and Akt hypophosphorylation in mesothelioma cell lines. Insulin-like growth factor receptor inhibition led to apoptotic cell death without affecting Akt phosphorylation. Platelet-derived growth factor receptor inhibition did not affect cellular survival or phosphoinositide-3 kinase signaling.

Conclusion: In malignant mesothelioma constitutive activation of phosphoinositide-3 kinase/Akt results in cellular survival and contributes to the malignant phenotype. We have demonstrated that epidermal growth factor receptor inhibition leads to apoptotic cell death through downregulation of phosphoinositide-3 kinase signaling in mesothelioma cell lines, whereas insulin-like growth factor receptor inhibition leads to apoptosis independent of phosphoinositide-3 kinase. Epidermal growth factor receptor, insulin-like growth factor receptor, and phosphoinositide-3 kinase inhibition might be clinically relevant in malignant mesothelioma.

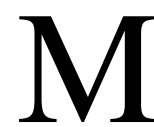
alignant mesothelioma (MM) is an aggressive neoplasm arising from the serosal surfaces of the pleural and peritoneal cavities. The incidence of this disease has increased steadily since 1970, and there are currently an estimated 3000 new cases per year in the United States. This trend 
is thought to reflect the effect of widespread occupational asbestos exposure from the 1940s to the 1960s. Recent studies have implicated exposure to SV40 tumor virus as well. ${ }^{1,2}$ Mesotheliomas arise from multipotential mesothelial cells that are capable of differentiating into an epithelial, sarcomatoid, or mixed neoplasm. The biologic behavior of mesothelioma remains poorly understood, and its clinical management is controversial. The treatment of mesothelioma has been disappointing because most patients die within 12 to 16 months of diagnosis, regardless of treatment regimen. Radiation therapy alone is generally ineffective because of the large volume of the primary tumor and its proximity to vital mediastinal structures, and response rates to chemotherapy have generally been less than $20 \%{ }^{3}$ Highly selected patients appear to benefit from trimodality therapy consisting of aggressive surgical resection followed by adjuvant radiation and chemotherapy. ${ }^{4}$ Failure of conventional therapies has led to interest in novel treatment approaches, including prodrug gene therapy, downregulation of the antiapoptotic gene product bcl-xl with histone deacetylase inhibition and antisense oligonucleotide strategies, and immunotherapy. ${ }^{5-8}$

The phosphoinositide-3 kinase (PI3K)/Akt signaling pathway is increasingly implicated in the development of a number of solid tumors, as well as their resistance to therapeutic measures, such as radiation and chemotherapy. ${ }^{9-12}$ Akt is a serine/threonine kinase that is constitutively activated in many human malignancies. The activation of Akt occurs downstream of PI3K. Activated PI3K generates a lipid second messenger, which is essential for translocation of Akt to the plasma membrane, where it is phosphorylated and activated by phosphoinositide-dependent kinase 1. Phosphorylated Akt then conveys downstream signals, promoting cellular proliferation and survival over apoptosis. ${ }^{13,14}$ Activity of the PI3K/Akt pathway is negatively regulated by the phosphatase and tensin analog (PTEN) tumor suppressor gene. We have previously demonstrated that forced overexpression of PTEN in MM cell lines by adenoviral gene transfer resulted in Akt hypophosphorylation and apoptotic cell death. ${ }^{15} \mathrm{We}$ have also demonstrated that resected mesothelioma specimens exhibit high levels of phosphorylated Akt on immunohistochemistry, indicating constitutive activation of this signaling pathway. Furthermore, PI3K inhibition resulted in Akt hypophosphorylation, engendered apoptotic cell death in vitro, and resulted in reduction of tumor burden in vivo in a mouse xenograft model of mesothelioma (manuscript submitted).

PI3K is recruited to the cell membrane and activated by the ligand-dependent activation of growth factor receptor tyrosine kinases (RTKs). These growth factor receptors are known to be overexpressed on the cell surface of many tumor types. This article presents work evaluating which RTKs are present in $\mathrm{MM}$ and their contribution to the constitutive activation of the PI3K/Akt signaling pathway in this treatment-resistant neoplasm.

\section{Materials and Methods \\ Cell Lines}

The human mesothelioma cell lines I-45 and REN were maintained in RPMI 1640 media supplemented with $10 \%$ fetal bovine serum (FBS), $100 \mu \mathrm{g} / \mathrm{mL}$ penicillin, and $100 \mu \mathrm{g} / \mathrm{mL}$ streptomycin and incubated in an atmosphere of 5\% carbon dioxide at $37^{\circ} \mathrm{C}$. I-45 is a human sarcomatous-type MM, p53 wild-type (donated generously by Dr Joseph Testa of the Fox Chase Institute, Philadelphia, Pa). REN is a human epithelialtype MM and p53 mutant (developed by WRS). The SV40 Tag-transformed human mesothelial cell line Met5a was purchased from American Type Culture Collection (Manassas, Va). Met5a was maintained in Medium 199 supplemented with $10 \% \mathrm{FBS}, 1 \mathrm{ng} / \mathrm{mL}$ epidermal growth factor (EGF), $400 \mathrm{nmol} / \mathrm{L}$ hydrocortisone, $100 \mu \mathrm{g} / \mathrm{mL}$ penicillin, and $100 \mu \mathrm{g} / \mathrm{mL}$ streptomycin and incubated in an atmosphere of $5 \%$ carbon dioxide at $37^{\circ} \mathrm{C}$.

\section{Materials}

Polyclonal antibodies to phosphorylated Akt (Ser 473), Akt, insulin-like growth factor (IGF) $1 \mathrm{R}-\alpha$, and platelet-derived growth factor receptor (PDGFR) $\beta$, as well as anti-rabbit IgG, were obtained from Cell Signaling (Beverly, Mass). Polyclonal antibodies to epidermal growth factor receptor (EGFR), HER2/ neu, and actin were obtained from Santa Cruz Biotechnology (Santa Cruz, Calif). AG 538 (IGF receptor [IGFR] inhibitor) and AG 1478 (EGFR inhibitor) were obtained from Sigma-Aldrich (St Louis, Mo). AG 1295 (PDGFR inhibitor) was obtained from Calbiochem (San Diego, Calif). AG 538, AG 1478, and AG 1295 were reconstituted in dimethyl sulfoxide (DMSO) at concentrations of 82,16 , and $47 \mathrm{mmol} / \mathrm{L}$, respectively, and then further diluted to desired concentrations in RPMI 1640 media supplemented with $10 \%$ FBS.

\section{In Vitro Assay of Cellular Viability}

The XTT colorimetric assay (Roche Diagnostics, Indianapolis, Ind) was used to determine cellular viability after treatment with AG 538, AG 1478, and AG 1295. Cells were plated on 96-well plates at a concentration of 2500 cells per well. After allowing 24 hours for adherence, cells were treated with serial dilutions of AG 538 (range, 0-425 $\mu \mathrm{mol} / \mathrm{L}$ ), AG 1478 (range, 0-159 $\mu \mathrm{mol} / \mathrm{L}$ ), AG 1295 (range, 0-215 $\mu \mathrm{mol} / \mathrm{L}$ ), and DMSO (range, 0\%-0.5\%) in RPMI plus 10\% FBS. Seventy-two hours after exposure, the XTT assay was performed per protocol supplied by the manufacturer. In brief, $50 \mu \mathrm{L}$ of XTT reagent was added to each well, and the plates were incubated at $37^{\circ} \mathrm{C}$ for 4 hours. The plates were then analyzed with a colorimetric microplate reader at a wavelength of $450 \mathrm{~nm}$ (Dynatech Labs, Langley, Va). Analysis of data was performed with Microsoft Excel (Microsoft Corp, Redmond, Wash). These experiments were performed in triplicate. 


\section{In Vitro Protein Expression}

Western blot analysis was performed with total cell lysates prepared by lysing plated cell monolayers with sodium dodecylsulfate-polyacrylamide gel electrophoresis sample buffer. Samples were collected when cell monolayers were approximately $70 \%$ confluent to determine the relative expression of EGFR, HER2/ neu, IGFR, and PDGFR in the I-45, REN, and Met5a cell lines. I-45 and REN cells were plated in RPMI plus $10 \%$ FBS and allowed 24 hours for adherence to determine phosphorylated Akt and Akt expression after RTK inhibition. Samples were collected $4,12$, and 24 hours after treatment with AG 538 ( $85 \mu \mathrm{mol} / \mathrm{L}), \mathrm{AG}$ $1478(15 \mu \mathrm{mol} / \mathrm{L})$, and AG 1295 (45 $\mu \mathrm{mol} / \mathrm{L})$. An untreated control sample was also collected. The protein content of each cell lysate was quantified with the BCA protein assay (Pierce, Rockford, Ill). Each lane on a sodium dodecylsulfate polyacrylamide gel was loaded with $50 \mu \mathrm{g}$ of cell lysate, and the samples were electrophoresed to separate proteins under reducing conditions. After electrophoresis, the proteins were transferred to high-bond nitrocellulose membranes (Amersham, Piscataway, NJ). The membranes were then incubated with primary and secondary antibodies and developed with the Lumiglo chemiluminescence reagents (Cell Signaling).

\section{Apoptosis Assay}

Apoptotic cell death was evaluated on the basis of changes in flow cytometric characteristics. Fluorescence-activated cell sorter (FACS) analysis was performed as follows: after exposure to RTK inhibitors for 96 hours, cells were trypsin digested, collected by means of centrifugation, resuspended in phosphate-buffered saline, and fixed in $70 \%$ ethanol at $-20^{\circ} \mathrm{C}$ overnight. After centrifugation, cells were washed in phosphate-buffered saline and resuspended in a propidium iodide staining solution containing RNase (Roche Diagnostics). Specimens were incubated in the dark for 30 minutes at $37^{\circ} \mathrm{C}$ and then analyzed with the use of an EPICS Profile II flow cytometer (Coulter Corp, Hialeah, Fla). An analysis region was set on the basis of the negative controls, and the percentage of sub-G1 cells was calculated from this region. These experiments were performed in triplicate. Statistical analysis was performed with the Student $t$ test.

\section{Results}

\section{Mesothelioma Cell Lines Highly Express EGFR, IGF-1R- $\alpha$, and PDGFR- $\beta$}

Cell lysates from I-45, REN, and Met5a were analyzed by means of Western blot analysis to determine the relative expression of EGFR, HER2/neu, IGF-1R- $\alpha$, and PDGFR- $\beta$ (Figure 1). EGFR is highly expressed in both MM cell lines in comparison with Met5a, although expression in the epithelial-type line (REN) appears to be greater than in the sarcomatous-type line (I-45). HER2/neu does not appear to be highly expressed in either MM cell line. IGF-1R- $\alpha$ and PDGFR- $\beta$ expression appear to be equivalent in I-45 and REN, with both MM cell lines exhibiting greater expression than Met5a.

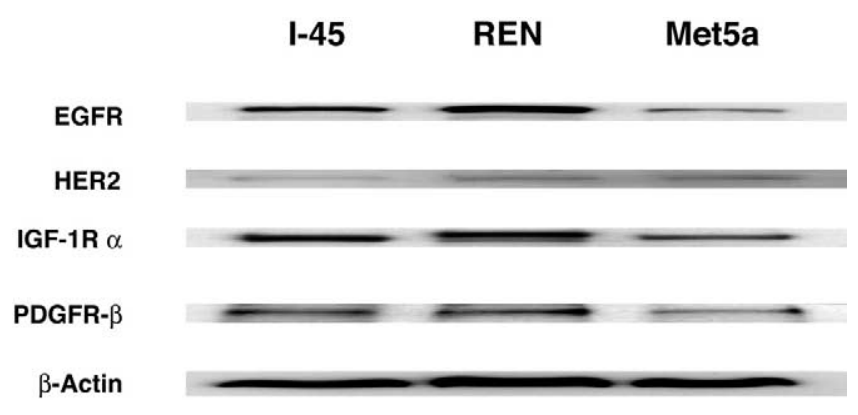

Figure 1. Western blot analysis of receptor tyrosine kinase protein expression in 2 MM cell lines (I-45 and REN) and a mesothelial cell line (Met5a). EGFR, IGF-1R- $\alpha$, and PDGFR- $\beta$ are highly expressed in both $M M$ cell lines in comparison with Met5a. HER2/neu actin is not highly expressed in either MM line. $\beta$-Actin expression is shown as a control.

\section{Cellular Viability In Vitro After Receptor Tyrosine Kinase Inhibition}

A colorimetric (XTT) assay was performed to assess the effects of anti-EGFR (AG 1478), anti-IGFR (AG 538), and anti-PDGFR (AG 1295) kinase inhibitors on cellular viability in both MM cell lines. EGFR kinase inhibition reduced cellular viability in a dose-dependent fashion in both I-45 and REN cells (Figure 2, A). Analysis of the resulting viability curve yielded an inhibitory concentration of 50\% $\left(\mathrm{IC}_{50}\right)$ dose of $15 \mu \mathrm{mol} / \mathrm{L} \mathrm{AG} 1478$ for both cell lines. IGFR kinase inhibition reduced cellular viability in a dose-dependent fashion in both MM cell lines, with I-45 displaying increased sensitivity than REN (Figure 2, $B$ ). The $\mathrm{IC}_{50}$ dose of AG 538 was determined to be approximately $85 \mu \mathrm{mol} / \mathrm{L}$ for both cell lines. PDGFR kinase inhibition reduced cellular viability in both I-45 and REN only at concentrations greater than previously reported. ${ }^{16}$ The $\mathrm{IC}_{50}$ dose of AG 1295 was determined to be approximately 140 $\mu \mathrm{mol} / \mathrm{L}$ for both cell lines (Figure 2, C). Tyrosine kinase inhibitors are known to lose their specificity as their concentration increases. Because this concentration is much higher than the dose previously reported in other tumor types, we elected to use a more appropriate concentration for further studies $(45 \mu \mathrm{mol} / \mathrm{L})$.

\section{Apoptotic Cell Death After Receptor Tyrosine Kinase Inhibition}

Cellular DNA content was examined with FACS analysis to determine whether the decrease in cellular viability noted previously was due to apoptosis. After exposure of mesothelioma cell lines to tyrosine kinase inhibitors for 96 hours, cell-cycle analysis was performed after propidium iodide staining to quantify the percentage of cells in the sub-G1 phase (Figure 3). After treatment with AG $1478(15 \mu \mathrm{mol} /$ L), a significant percentage of cells in both cell lines was 
EGFR Inhibitor - 1-45

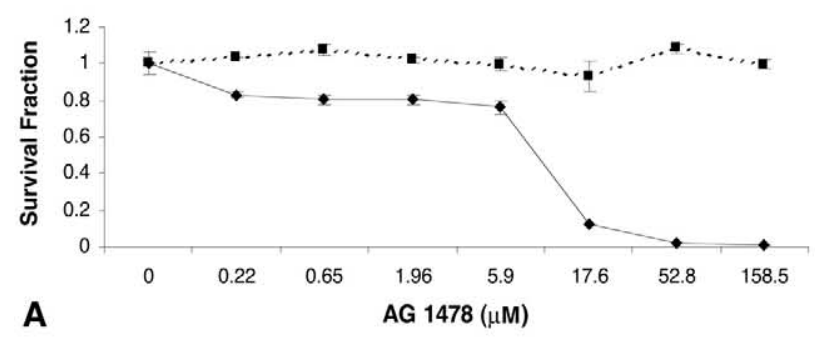

IGFR Inhibitor - I-45

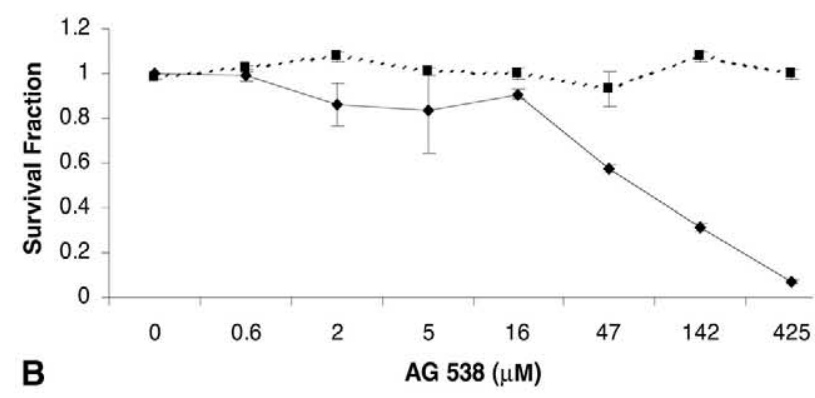

PDGFR Inhibitor - 1-45

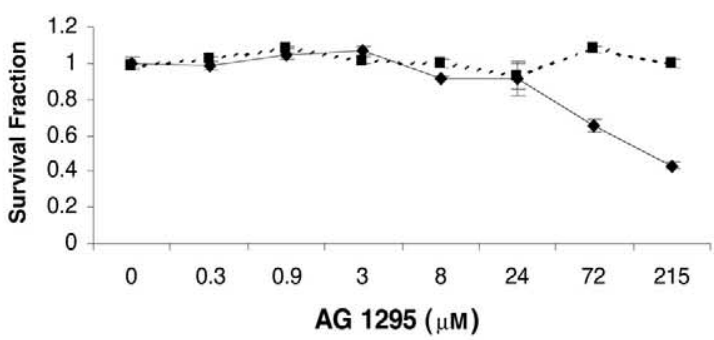

EGFR Inhibitor - REN

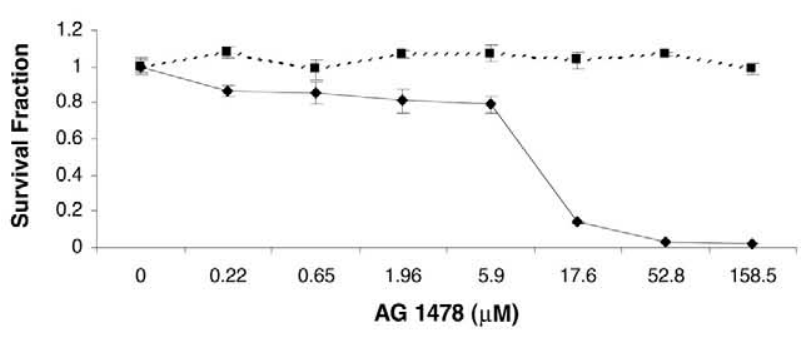

IGFR Inhibitor - REN

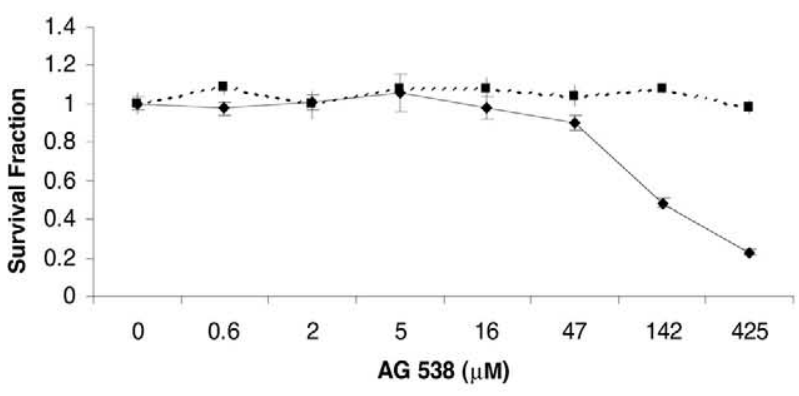

PDGFR Inhibitor - REN

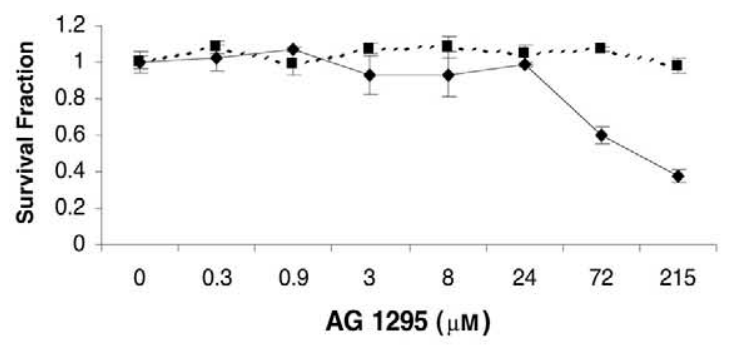

Figure 2. Cell viability assay (XTT) of mesothelioma cell lines after exposure to receptor tyrosine kinase inhibitors. A, EGFR kinase inhibition (AG 1478) reduced cellular viability in a dose-dependent fashion in both I-45 and REN (range, 0-159 $\mu \mathrm{mol} / \mathrm{L}$ ). B, IGFR kinase inhibition (AG 538) reduced cellular viability in a dose-dependent fashion in both MM cell lines, with I-45 displaying greater sensitivity than REN (range, 0-425 $\mu \mathrm{mol} / \mathrm{L}$ ). C, PDGFR kinase inhibition (AG 1295) reduced cellular viability in both I-45 and REN only at concentrations greater than previously reported in other cell lines (range, 0-215 $\mu \mathrm{mol} / \mathrm{L}$ ). DMSO carrier is included as a control for the 3 inhibitors (range, $0 \%-0.5 \%)$.

noted to have undergone apoptotic cell death in comparison with a control group treated with DMSO (I-45: $16.6 \%$ vs $3.2 \%, P<.05$; REN: $16.9 \%$ vs $2.3 \%, P<.05)$. AG 538 exposure $(85 \mu \mathrm{mol} / \mathrm{L})$ resulted in significant apoptosis in the sarcomatous line I-45 $(24.9 \%$ vs $3.2 \%, P<.05)$. However, AG 538 did not result in significant apoptosis in the epithelial line REN (3.6\% vs $2.3 \%, P>.05)$. Treatment with AG $1295(45 \mu \mathrm{mol} / \mathrm{L})$ did not result in significant programmed cell death in either cell line (I-45: $3.1 \%$ vs $3.2 \%, P>.05$; REN: $2.4 \%$ vs $2.3 \%, P>.05)$.

\section{PI3K Signaling After Receptor Tyrosine Kinase Inhibition}

Cell-surface RTKs are known to activate the PI3K/Akt signaling pathway in a ligand-dependent fashion. Western blot analysis for phosphorylated Akt was performed on cell lysates after exposure to tyrosine kinase inhibitors to determine whether EGFR, IGFR, or PDGFR is responsible for the constitutive activation of this pathway in mesothelioma (Figure 4). Inhibition of EGFR tyrosine kinase activity (AG 1478) resulted in decreased signaling through the PI3K pathway in both the I-45 
FACS - I-45

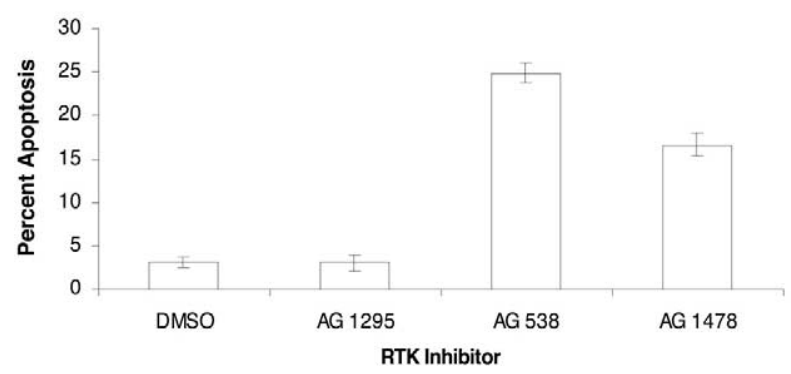

FACS - REN

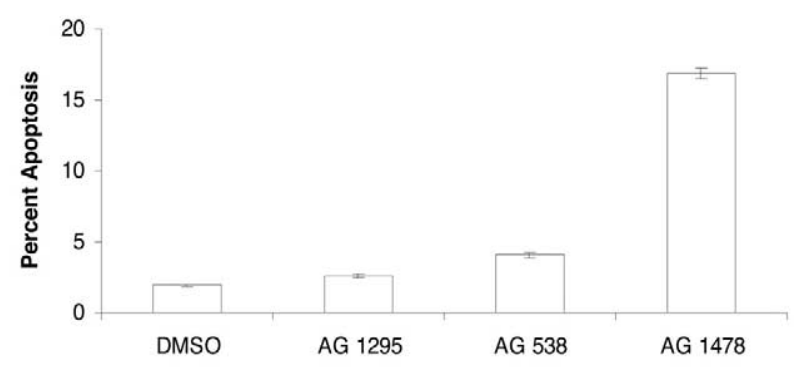

Figure 3. Sub-G1 fluorescence-activated cell-sorter analysis after exposure of mesothelioma cell lines to receptor tyrosine kinase inhibitors. The apoptotic percentage of cells 96 hours after exposure to AG 1478 (15 $\mu \mathrm{mol} / \mathrm{L})$ was increased significantly in both I-45 $(16.6 \%$ vs $3.2 \%, P<.05)$ and REN $(16.9 \%$ vs $2.3 \%, P<.05)$ compared with DMSO control. AG 538 (85 $\mu \mathrm{mol} / \mathrm{L})$ exposure led to a significant increase in the apoptotic population in I-45 (24.9\% vs $3.2 \%$, $P<.05)$ but not REN (3.6\% vs $2.3 \%, P>.05)$. Treatment with AG 1295 (45 $\mu \mathrm{mol} / \mathrm{L})$ did not result in significant programmed cell death in either I-45 $(3.1 \%$ vs $3.2 \%, P>.05)$ or $\operatorname{REN}(2.4 \%$ vs $2.3 \%, P>.05)$.

and REN cell lines, as evidenced by a time-dependent decrease in phosphorylated Akt on Western blot analysis. Neither IGFR nor PDGFR inhibition affected the Akt phosphorylation status in either cell line.

\section{Discussion}

Despite advances in modern oncologic care, the prognosis for patients with MM remains poor. Mesothelioma is typically resistant to commonly used apoptotic stimuli, such as chemotherapy and radiation. Activated PI3K, by way of downstream effectors, is known to control cellular functions, such as cellcycle progression and prevention of apoptosis, in many solid tumor types. In previous studies our laboratory has demonstrated that this signaling pathway is constitutively active in resected mesothelioma specimens and that PI3K inhibition by means of a small molecular kinase inhibitor (LY294002) or forced overexpression of a negative regulator (PTEN) engenders apoptotic cell death in mesothelioma cell lines.

Cell-surface receptors for peptide growth factors are known to activate the PI3K signaling pathway. EGFR is one such receptor known to be overexpressed at the RNA level, the protein level, or both by many human malignancies, such as those of the breast, colon, pancreas, lung, and upper aerodigestive tract. ${ }^{17,18}$ There are several existing studies that suggest that EGFR might be important in the pathogenesis of mesothelioma. In 1990, Dazzi and colleagues ${ }^{19}$ found that $68 \%$ of mesothelioma specimens stained positively for EGFR by means of immunohistochemistry and that EGFR positivity was more common in the epithelial subtype. In studying the immunohistochemical expression of EGFR and its ligand, transforming growth factor (TGF) $\alpha$, Cai and associates ${ }^{20}$ found that $76 \%$ of mesotheliomas expressed TGF- $\alpha$, whereas $45 \%$ expressed EGFR, indicating the possibility of an EGFR autocrine loop. EGFR expression in mesothelial cells has also been linked to asbestos exposure in tissue culture. Pache and co- workers ${ }^{21}$ discovered that SV40-transformed human mesothelial cells (Met5a) exposed to asbestos fibers in vitro overexpressed EGFR compared with control cells and that EGFR expression was related to increasing fiber length of crocidolite asbestos. A similar study confirmed these findings in rat pleural mesothelial cells. ${ }^{22}$ Janne and colleagues $^{23}$ demonstrated that $4 \mathrm{MM}$ cell lines expressed EGFR and that EGFR inhibi-

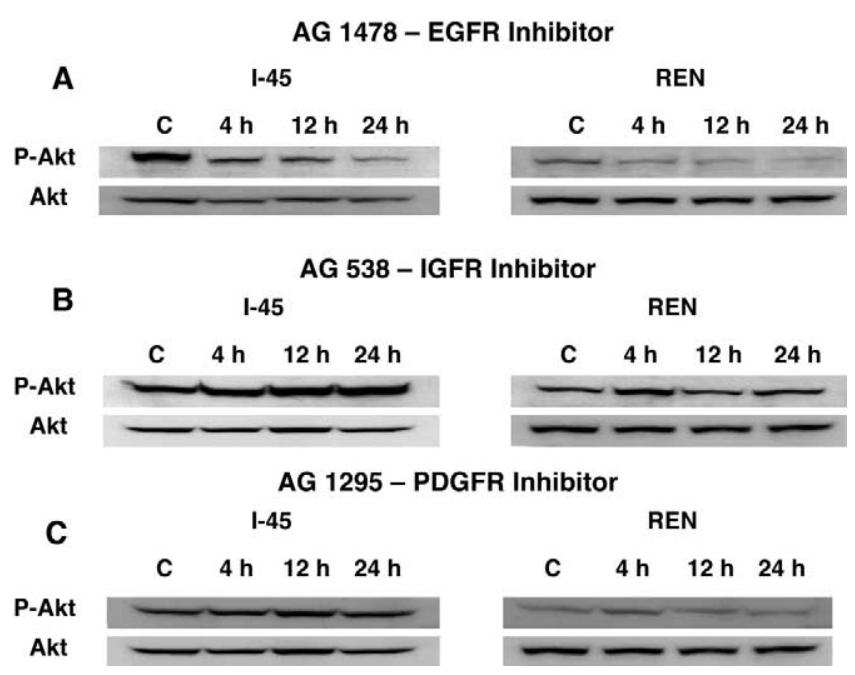

Figure 4. Western blot analysis of phosphorylated Akt (P-Akt) protein expression after exposure of mesothelioma cell lines to receptor tyrosine kinase inhibitors. A, Inhibition of EGFR tyrosine kinase activity (AG 1478, $15 \mu \mathrm{mol} / \mathrm{L}$ ) resulted in decreased signaling through the PI3K pathway in both I-45 and REN, as evidenced by a time-dependent decrease in phosphorylated Akt. B and C, Neither IGFR (AG 538, $85 \mu \mathrm{mol} / \mathrm{L}$ ) nor PDGFR (AG 1295, 45 $\mu \mathrm{mol} / \mathrm{L}$ ) inhibition affected the phosphorylated Akt status in either cell line. Total Akt expression is shown as control and was unaffected by differential treatment. 
tion with ZD1839 resulted in growth inhibition and G1 cellcycle arrest. Also, She and associates ${ }^{24}$ noted that ZD1839 potentiated the radiation response of mesothelioma xenografts in nude mice, with many animals demonstrating complete regression with no tumor regrowth.

The IGF-1 receptor is known to mediate PI3K signaling and is commonly expressed on many tumor types, including breast, prostate, colon, and lung cancer. ${ }^{25}$ In 1993, Lee and colleagues ${ }^{26}$ reported that both normal mesothelial and mesothelioma cell lines express IGF-1 and IGF-1R mRNA, indicating the possibility of an autocrine loop. Also, Pass and associates ${ }^{27}$ have reported that an IGF-1 receptor antisense expression vector led to a decrease in proliferation and tumorigenicity in a hamster mesothelioma cell line.

PDGFR is known to be present on tumor cells, and PDGFR inhibitors are currently in use in the treatment of chronic myelogenous leukemia and gastrointestinal stromal tumors. ${ }^{28}$ Also, activated PDGFR has been shown to induce PI3K signaling. ${ }^{29}$ In 1991, Versnel and coworkers ${ }^{30}$ demonstrated that mesothelioma cell lines express PDGF- $\beta$ receptor mRNA and protein, whereas normal mesothelial cells express PDGF- $\alpha$ receptors. A similar expression pattern has been demonstrated in clinical specimens by means of immunohistochemistry. ${ }^{31}$ Moreover, overexpression of PDGF- $\alpha$ through a retroviral expression vector resulted in tumorigenic conversion of a human mesothelial cell line. ${ }^{32}$

In the current study we have demonstrated that the relative expression of EGFR, IGF-1R, and PDGFR is greater in $2 \mathrm{MM}$ cell lines in comparison with a transformed mesothelial line. However, only EGFR appears to be involved in the constitutive activation of the PI3K/Akt pathway noted previously in mesothelioma. Inhibition of the EGFR tyrosine kinase engenders apoptotic cell death in both mesothelioma cell lines and leads to downregulation of the PI3K signaling pathway, as evidenced by Akt hypophosphorylation. Moreover, after stimulation with EGF $(10 \mathrm{ng} / \mathrm{mL})$, both I-45 and REN demonstrate Akt hyperphosphorylation by means of Western blot analysis. Interestingly, inhibition of IGF-1R resulted in decreased cellular viability and apoptosis in a sarcomatous-type mesothelioma cell line (I-45) but not in an epithelial-type mesothelioma cell line (REN). IGFR inhibition did not appear to affect PI3K signaling in either cell line. An inhibitor of PDGFR did not affect viability, apoptosis, or PI3K signaling in either of the cell lines. A previous study of signal transduction events after exposure of rat pleural mesothelial cells to asbestos yielded similar results. In this study, Zanella and colleagues ${ }^{33}$ noted that asbestos fibers induced phosphorylation of mitogen-activated protein kinase and extracellular signal-regulated kinase (ERK) 1 and 2. Moreover, they reported that stimulation of these mesothelial cells with the EGFR ligands EGF and TGF- $\alpha$ similarly induced phosphorylation of ERK 1 and 2, whereas stimulation with IGF-1 and PDGF isoforms did not affect ERK phosphorylation status. Our study suggests that therapies targeting EGFR, IGFR, PI3K, and Akt might be clinically relevant in mesothelioma. Two anti-EGFR therapies are currently in clinical use: the monoclonal antibody C225 (Erbitux) and the small molecule inhibitor ZD1839 (Iressa). Targeted therapies for IGFR and Akt are currently in various stages of development. Certainly further investigation with such agents in mesothelioma is warranted in an effort to improve the currently dismal prognosis of this treatment-resistant neoplasm.

\section{References}

1. Rusch VW. Mesothelioma and less common pleural tumors. In: Pearson FG, Cooper JD, Deslauriers J, Ginsberg RJ, Hiebert CA, Patterson GA, et al, editors. Thoracic surgery. 2nd ed. Philadelphia: Churchill Livingstone; 2002. p. 1241-63.

2. Carbone M, Kratzke RA, Testa JR. The pathogenesis of mesothelioma. Semin Oncol. 2002;29:2-17.

3. Ong ST, Vogelzang NJ. Chemotherapy in malignant pleural mesothelioma. A review. J Clin Oncol. 1996;14:1007-17.

4. Sugarbaker DJ, Flores RM, Jaklitsch MT, Richards WG, Strauss GM, Corson JM, et al. Resection margins, extrapleural nodal status, and cell type determine postoperative long term survival in trimodality therapy of malignant pleural mesothelioma: results in 183 patients. $J$ Thorac Cardiovasc Surg. 1999;117:54-63.

5. Smythe WR, Hwang HC, Amin KM, Eck SL, Davidson BL, Wilson $\mathrm{JM}$, et al. Use of a recombinant adenovirus to transfer the herpes simplex thymidine kinase (HSVtk) gene to thoracic neoplasms: an effective in vitro drug sensitization system. Cancer Res. 1994;54: 2055-9.

6. Cao XX, Mohiuddin I, Ece F, McConkey DJ, Smythe WR. Histone deacetylase inhibitor down-regulation of bcl-xl gene expression leads to apoptotic cell death in mesothelioma. Am J Respir Cell Mol Biol. 2001;25:562-8.

7. Smythe WR, Mohiuddin I, Ozveran M, Cao XX. Antisense therapy for malignant mesothelioma with oligonucleotides targeting the bcl-xl gene product. J Thorac Cardiovasc Surg. 2002;123:1191-8.

8. Nowak AK, Lake RA, Kindler HL, Robinson BW. New approaches for mesothelioma: biologics, vaccines, gene therapy, and other novel agents. Semin Oncol. 2002;29:82-96.

9. Philip AJ, Campbell IG, Leet C, Vincan E, Rockman SP, Whitehead $\mathrm{RH}$, et al. The Phosphatidyl $3^{\prime}$-kinase p85 $\alpha$ gene is an oncogene in human ovarian and colon tumors. Cancer Res. 2001;61:7426-9.

10. Lin X, Bohle AS, Dohrmann P, Leuschner I, Schulz A, Kremer B, et al. Overexpression of phosphatidylinositol 3-kinase in human lung cancer. Langenbeck Arch Surg. 2001;386:293-301.

11. Brognard J, Clark AS, Yucheng N, Dennis PA. Akt/protein kinase B is constitutively active in non-small cell lung cancer cells and promotes cellular survival and resistance to chemotherapy and radiation. Cancer Res. 2001;61:3986-97.

12. Hu L, Hofmann J, Lu Y, Mills GB, Jaffe RB. Inhibition of phosphatidylinositol $3^{\prime}$-kinase increases efficacy of paclitaxel in in vitro and in vivo ovarian cancer models. Cancer Res. 2002;62:1087-92.

13. Nicholson KM, Anderson NG. The protein kinase B/Akt signalling pathway in human malignancy. Cell Signal. 2002;14:381-95.

14. Chang F, Lee JT, Navolanic PM, Steelman LS, Shelton JG, Blalock WL, et al. Involvement of PI3K/Akt pathway in cell cycle progression, apoptosis, and neoplastic transformation: a target for cancer chemotherapy. Leukemia. 2003;17:590-603.

15. Mohiuddin I, Cao X, Ozvaran MK, Zumstein L, Chada S, Smythe WR. Phosphatase and tensin analog gene overexpression engenders cellular death in human malignant mesothelioma cells via inhibition of Akt phosphorylation. Ann Surg Oncol. 2002;9:310-6.

16. Uren A, Merchant MS, Sun CJ, Vitolo MI, Sun Y, Tsokos M, et al. Beta-platelet-derived growth factor receptor mediates motility and growth of Ewing's sarcoma cells. Oncogene. 2003;22:2334-42. 
17. Arteaga CL. The epidermal growth factor receptor: from mutant oncogene in nonhuman cancers to therapeutic target in human neoplasia. J Clin Oncol. 2001;19:32s-40s.

18. Glover KY, Perez-Soler R, Papadimitradopoulou VA. A review of small-molecule epidermal growth factor receptor-specific tyrosine kinase inhibitors in development for non-small cell lung cancer. Semin Oncol. 2004;31(suppl 1):83-92.

19. Dazzi H, Hasleton PS, Thatcher N, Wilkes S, Swindell R, Chatterjee AK. Malignant pleural mesothelioma and epidermal growth factor receptor (EGF-R). Relationship of EGF-R with histology and survival using fixed paraffin embedded tissue and the F4, monoclonal antibody. Br J Cancer. 1990;61:924-6.

20. Cai YC, Roggli V, Mark E, Cagle PT, Fraire AE. Transforming growth factor alpha and epidermal growth factor receptor in reactive and malignant mesothelial proliferations. Arch Pathol Lab Med. 2004;128: 68-70.

21. Pache JC, Janssen Y, Walsh ES, Quinlan TR, Zanella CL, Low RB, et al. Increased Epidermal growth factor-receptor protein in a human mesothelial cell line in response to long asbestos fibers. Am J Pathol. 1998;152:333-40.

22. Faux SP, Houghton CE, Hubbard A, Patrick G. Increased expression of epidermal growth factor receptor in rat pleural mesothelial cells correlates with carcinogenicity of mineral fibres. Carcinogenesis. 2001;12:2275-80.

23. Janne PA, Taffaro ML, Salgia R, Johnson BE. Inhibition of epidermal growth factor receptor signaling in malignant pleural mesothelioma. Cancer Res. 2002;62:5242-7.

24. She Y, Lee F, Chen J, Haimovitz-Friedman A, Miller VA, Rusch VR, et al. The epidermal growth factor receptor tyrosine kinase inhibitor ZD1839 selectively potentiates radiation response of human tumors in nude mice, with a marked improvement of therapeutic index. Clin Cancer Res. 2003;9:3773-8.

25. LeRoith D, Roberts CT. The insulin-like growth factor system and cancer. Cancer Lett. 2003;195:127-37.

26. Lee TC, Zhang Y, Aston C, Hintz R, Jagirdar J, Perle MA, et al. Normal human mesothelial cells and mesothelioma cell lines express insulin-like growth factor 1 and associated molecules. Cancer Res. 1993;53:2858-64.

27. Pass HI, Mew DJ, Carbone M, Matthew WA, Donington JS, Baserga $\mathrm{R}$, et al. Inhibition of hamster mesothelioma tumorigenesis by an antisense expression plasmid to the insulin-like growth factor-1 receptor. Cancer Res. 1996;56:4044-8.

28. George D. Targeting PDGF receptors in cancer-rationales and proof of concept clinical trials. Adv Exp Med Biol. 2003;532:141-51.

29. Franke TF, Yang SI, Chan TO, Datta K, Kazlauskas A, Morrison DK, et al. The Protein kinase encoded by the Akt proto-oncogene is a target of the PDGF-activated phosphatidylinositol 3-kinase. Cell. 1995;81: 727-36.

30. Versnel MA, Claesson-Welsh L, Hammacher A, Bouts MJ, van der Kwast TH, Eriksson A, et al. Human malignant mesothelioma cell lines express PDGF beta-receptors whereas cultured normal mesothelial cells express predominantly PDGF alpha-receptors. Oncogene. 1991;6:2005-11

31. Ascoli V, Scalzo CC, Facciolo F, Nardi F. Platelet-derived growth factor receptor immunoreactivity in mesothelioma and nonneoplastic mesothelial cells in serous effusions. Acta Cytol. 1995;39:61322

32. Van der Meeren A, Seddon MB, Betsholtz CA, Lechner JF, Gerwin BI. Tumorigenic conversion of human mesothelial cells as a consequence of platelet-derived growth factor-A chain overexpression. Am J Respir Cell Mol Biol. 1993;8:214-21.

33. Zanella CL, Posada J, Tritton TR, Mossman BT. Asbestos causes stimulation of the extracellular signal-regulated kinase 1 mitogenactivated protein kinase cascade after phosphorylation of the epidermal growth factor receptor. Cancer Res. 1996;56:5334-8.

\section{Discussion}

Dr Dao M. Nguyen (Bethesda, Md). I just have a few questions for you regarding the levels of EGFR, PDGFR, or IGFR. You compared the levels of these receptors on cancer cells with those of transformed normal cells. Have you studied the levels of these receptors on primary normal cells, like skin fibroblasts or keratinocytes, or primary normal human bronchial epithelial cells?

Dr Rascoe. No, sir, we have not looked at that. As you may know, mesothelial cells are very difficult to culture in vitro, and therefore we use a transformed cell line. We have not compared that with an endothelial cell line or keratinocytes.

Dr Nguyen. Right. I realize that limitation. Any mesenchymaderived cells should be a good representation of normal control cells. The other thing is that you used very high concentrations of these pharmacologic inhibitors, up to a range of $10 \mu \mathrm{mol} / \mathrm{L}$ or more. How selective are these inhibitors when you use a micromolar concentration?

Dr Rascoe. That is a very good point. The $\mathrm{IC}_{50}$ doses for EGFR and IGFR inhibition that we are reporting are similar to the doses reported in other tumor types in the literature. However, as you know, small molecular inhibitors of tyrosine kinases lose specificity as their concentration is increased. We see EGFR inhibition at approximately $10 \mu \mathrm{mol} / \mathrm{L}$ in our cell lines.

Dr Nguyen. That is true and very important because if you try to translate that to a clinical study, as you know, in the phase I/phase II Iressa studies, the maximum clinically achievable concentration of Iressa is around $2 \mu \mathrm{mol} / \mathrm{L}$.

Dr Rascoe. We are now attempting to confirm these studies with monoclonal antibodies. As you know, there are anti-EGFR and IGFR monoclonal antibodies that are commercially available. These antibodies do not lose specificity with increasing concentration and are therefore a purer inhibitor than the small molecule inhibitors.

Dr Nguyen. Just a technical point. How good are these PDGFR antagonists you are using? Have you been able to get the imatinib mesylate (Gleevec)?

Dr Rascoe. We have not used imatinib mesylate or gefitinib (Iressa).

Dr W. Roy Smythe (Temple, Tex). I would like to respond to one of Dao's questions. I am not sure whether the next presentation will address this, but we have stained a number of mesothelioma specimens for EGFR expression, and there is a significant difference in the tumor and surrounding normal cells in vivo, which I think is a reasonable way to answer that, although we have not looked at other normal cell types.

The other thing that Dr Rascoe did not mention about the selectivity is that if you treat Met5A with the inhibitors that we have shown here at the same concentrations, there is basically no effect.

Dr Jack Roth (Houston, Tex). I have just one comment. You saw a spectrum of sensitivity to these kinase inhibitors, which is very relevant to the clinical situation, in which many patients are not very responsive to some of the known kinase inhibitors. One of the emerging observations here is that there are probably mutations, for example, in EGFR, and those patients who have mutations in their tumors in this receptor are the ones who appear to be responsive. Therefore, I wondered whether you have had an opportunity to investigate this in some of your responsive and nonresponsive cell lines. Have you looked at the status of the receptor? Are there mutations? Are there overexpressions? Is there anything that you can think of to explain this difference in sensitivity? 
Dr Rascoe. We have not looked specifically at the presence of mutations. It does appear that in our 2 cell lines, REN and I-45, EGFR is constitutively phosphorylated on Western blot analysis, even in serum-starved cells. Therefore there is a possibility that the receptor is mutated. However, we have not looked at that yet.

\section{JTCVS On-Line Manuscript Submission and Review Please visit http://www.editorialmanager.com/jtcvs/}

Effective September 15, 2001, authors and reviewers may submit manuscripts and reviews electronically via Editorial Manager, our new Web-based system with full electronic submission, review, and status update capabilities.

As we move from paper to electronic submissions, the Editorial Office will make proxy submissions of all manuscripts accompanied by a diskette containing the electronic files of the text, tables, and figures. Editors, authors, and reviewers will receive automatic e-mails when significant events occur.

We strongly encourage all authors and reviewers to use Editorial Manager. Although we will continue to accommodate the submission of paper manuscripts for some months, our goal is to be completely electronic within 9 to 12 months.

All individuals currently in our database for whom we have e-mail addresses will receive via e-mail a system-assigned username and password that can be used to log in to the system without prior registration. All those not receiving the e-mail must register the first time they use the system.

As with any broad systemic change, the conversion to the new system will take some time to complete. We ask your patience as we replace our in-office database with the new system. We also encourage you to take advantage of the speed and efficiency that the new system will provide for us all: editor, author, reviewer, and publisher. 